\title{
Hospitalization of premature infants: parents' perceptions and revelations about nursing care
}

\author{
Internação de recém-nascidos prematuros: percepções dos pais e revelações acerca do \\ cuidar de enfermagem
}

Greice Machado Pieszak ${ }^{1}$, Andressa Moreira Paust ${ }^{1}$, Giovana Calcagno Gomes², Andrea Moreira Arrué ${ }^{3}$, Eliane Tatsch Neves ${ }^{4}$, Letícia Martins Machado ${ }^{1}$

\begin{abstract}
Objective: to describe the perceptions of parents about the hospitalization of premature infants and the care provided by nursing staff. Methods: qualitative study in a Neonatal Intensive Care Unit with 14 parents. Medical records checking, interview with the participants and thematic content analysis were carried out. Results: parents reported surprise, fear, insecurity and guilt by hospitalization and prematurity. They mentioned as difficulties being in another city, leaving the other children and financial problems, and as facilitator factors trust and good relationship with the team and care availability. They showed fear of hospital discharge, however, they received the team's guidelines for home care. Conclusion: hospitalization motivates different feelings related to prematurity, financial and social issues and the distance from home and families. They showed learning through the bond and trust as an important activity of the nursing staff.
\end{abstract}

Descriptors: Infant, Newborn; Neonatology; Intensive Care Units, Neonatal; Nursing Care.

Objetivo: descrever as percepções dos pais acerca da internação de recém-nascidos prematuros e dos cuidados prestados pela equipe de enfermagem. Métodos: estudo qualitativo em uma Unidade de Terapia Intensiva Neonatal com 14 pais. Foi realizada consulta aos prontuários, entrevista com os participantes e análise de conteúdo temática. Resultados: os pais relataram surpresa, medo, insegurança e culpa pela internação e prematuridade. Referiram como dificuldades estar em outra cidade, deixar os outros filhos e problemas financeiros, e as facilidades foram confiança e bom relacionamento com a equipe e a disponibilidade de tecnologias de cuidado. Apontaram medo da alta hospitalar, entretanto, receberam orientações da equipe para o cuidado no domicílio. Conclusão: a internação motiva diferentes sentimentos relacionados à prematuridade, às questões de ordem financeira e social e o distanciamento dos lares e familiares. Evidenciaram o aprendizado, por meio do vínculo e da confiança como uma atividade importante da equipe de enfermagem.

Descritores: Recém-Nascido; Neonatologia; Unidades de Terapia Intensiva Neonatal; Cuidados de Enfermagem.

\footnotetext{
${ }^{1}$ Universidade Regional do Alto Uruguai e das Missões, Campus de Santiago. Santiago, RS, Brazil.

${ }^{2}$ Universidade Federal do Rio Grande. Rio Grande, RS, Brazil.

${ }^{3}$ Fundação Osvaldo Cruz Epidemiologia em Saúde Pública. Rio de Janeiro, RJ, Brazil.

${ }^{4}$ Universidade Federal de Santa Maria. Santa Maria, RS, Brazil. 


\section{Introduction}

Most hospitalizations in Neonatal Intensive Care Units are caused by prematurity, which concern newborns' parents, because they perceive this environment as unknown and scary. During pregnancy, the family prepares for the baby to arrive home soon after birth. However, when prematurity occurs and the parents witness their transfer to a Neonatal Intensive Care Unit, concerns, anxieties and fears can appear ${ }^{(1)}$.

A premature newborn is a baby born before 37 weeks of gestation. The factors that contribute to the premature birth are related to complications of pregnancy such as high blood pressure, infections, previous premature births, diabetes, heart disease, kidney disease, uterine anomaly, placenta abruption, smoking, alcohol and illicit drugs use $\mathrm{e}^{(2)}$.

The birth of a premature newborn, most of the time, needs hospitalization in Neonatal Intensive Care Unit. This place contains various intensive care technologies directed to increase neonate survival. The health team must have specialized scientific and humanized knowledge and is also responsible for making the environment friendlier and less impersonal ${ }^{(3)}$.

Nursing care is continuous during the permanence of the newborn in the Neonatal Intensive Care Unit, so it very important the parents' reception and involvement to clarify their doubts and reduce anxieties related to hospitalization and health condition of their children, which encourages confidence and strengthens bonds ${ }^{(4)}$. This reflects in the recovery, growth and development of the neonate and minimize the harmful effects caused by hospitalization ${ }^{(5)}$.

Nurses need to deepen their knowledge on the challenges experienced by parents in this context. So, the following question was asked: how parents perceive the hospitalization of their premature babies in the neonatal unit? The objective of study is to describe the perceptions of parents about the hospitalization of premature infants and the care provided by the nursing staff.

\section{Methods}

A qualitative research developed in a charitable hospital in the South of Brazil, reference institution in neonatal intensive care service in the region. Data collection took place in September and October 2016.

14 parents of premature infants participated in the study, 12 mothers and two fathers. The criteria for inclusion was: being a father and/or mother of premature newborn admitted in Neonatal Intensive Care Unit. The parents younger than 18 years old were excluded.

First, parents were invited to participate in the study. After the authorization, newborns were identified and characterized consulting the records to collect the following information: sex; birth weight; gestational age; number of previous pregnancies; type of delivery; main factor associated with prematurity; Apgar score and length of hospitalization in Neonatal Intensive Care Unit.

Later, the parents participated in an interview of two stages held in a private room in the hospital which ensured the privacy and autonomy of the participants. They were performed individually or with the couple through previously tested form and lasted, on average, 30 minutes. The words were transcribed in full and submitted to thematic content analysis ${ }^{(6)}$.

The first stage presented questions about marital status, age, education, household income, working activities, origin and religion. The second was conducted with open-ended questions: "how many people are there in your family? How was the pregnancy? What led to the premature delivery? How was the birth of your child? How do you feel about the prematurity? How are you living your child's hospitalization in the Neonatal Intensive Care Unit? What are your perceptions about the care provided to your child by the staff? What are the difficulties and facilitators you are experiencing right now? How do you participate taking care of your child?".

Thematic content analysis was performed in 
three phases: pre-analysis, which consisted in choosing the analyzed documents and retaking the initial research objectives; exploration of the material, in which data were classified to reach the text core of understanding; the results processing and interpretation to remark the information obtained, indicate inferences and realize interpretations interrelated with the initial objective ${ }^{(6)}$. Alphanumeric coding was used to classify the parents with the initial "P" followed by ordinal numbers, according to the sequence in which the interviews were transcribed.

The study complied with the formal requirements contained in the national and international regulatory standards for research involving human beings.

\section{Results}

The documental survey showed that half of the 12 neonates in the hospital were male, four weighed less than 1,000 $\mathrm{g}$ at birth, seven less than 2,500 $\mathrm{g}$ and only one weighed more than 2,500g. Their births took place between 25 and 36 weeks of gestation. It was found that eight women were primiparous and four, multiparous. As to the type of delivery, nine were cesarean sections and three vaginal births. In the Apgar test, four infants presented score $<2$ and eight $>6$ in the first minute, while in the fifth minute all newborns had an index $>7$.

The main factors associated with the occurrence of premature birth were six maternal infections; three had preeclampsia and eclampsia; two lost amniotic fluid; and one had a twin pregnancy where one of the twins died after birth. The length of stay in the Neonatal Intensive Care Unit varied from two to 60 days.

All participants had a stable relationship. Their age varied between 18 and 47 years old. With respect to the level of education, five completed high education, five had incomplete high school, three had complete elementary and one was studying at higher education. The family income ranged between one and four minimum wages. About working activities, only seven participants were employed. It is important to point out that the participants were from eight different cities in the countryside of Rio Grande do Sul, Brazil. As for religion, eight were Catholics, four evangelicals and two spiritualists.

After the thematic analysis, the following analytical categories emerged: pregnancy and birth of a premature child and premature newborn care through the support of the staff.

\section{Pregnancy and birth of a premature child}

All participants held prenatal care and had between three and 13 appointments. It was observed that most of them found out they were pregnant after the second month. It was reported they show commitment with the appointments and good relationship with the professionals involved. In prenatal care I was well accompanied, but the first month I didn't go to the doctor because I knew about pregnancy after some time, the pregnancy was already advanced (P3). I went to only three prenatal appointments, the doctor asked me to go once a month or only when I had the exams results (P7). I did the prenatal care right, about five appointments. I was already three months pregnant when I went to the doctor (P10). I went to all the appointments and in the last one I had an accident at home, I fell down and the doctor asked me to stay in the hospital, because I lost amniotic fluid (P11).

The predominant feelings about the premature birth of their children and hospitalization in Neonatal Intensive Care Unit were fear, uncertainty, surprise, stress, joy, confidence in the team, parents/children bonds broken and guilt. It was scary to know that our daughter would be premature, we were pretty scared, very scared, because we didn't expect that. At the time of delivery, the team talked and give me confidence and everything went pretty well (P3). To me, his birth (son) was very significant, we got bad to be in Neonatal Intensive Care Unit, we idealize we will be close to the baby after birth, but I know that he is in hospital because he is premature and to keep him alive (P9). The birth was good, even premature it was a joy, but the doctor said I could have prevented that and that made me feel so bad, I felt guilty. During delivery, I did my best so he will be born well (P10). It 
was wonderful, having a baby is a blessing and it all worked out. She had no complications, we've been through this in another pregnancy, we knew if she was born before she will be at NICU, at least here we have all the resources (P12).

About prematurity, participants reported anxiety and fear, because it is a new process with various barriers to be overcome. It's hard to deal with it. She is very tiny, she was born at six months and weighed $630 \mathrm{~g}$. As she is too small it could have happened something more serious with her (P2). At first, I was very sad that he went to Neonatal Intensive Care Unit, because I didn't expect him to be born premature, but it's for his own good. I trust the staff. They are very friendly with kids (P4). At first, we always think the worst, but as the baby is growing and recovering we're confident, I had already searched and prepared myself for any complications (P5).

However, despite the difficulties during newborns hospitalization, parents were empowered and confident about the care provided by the staff in charge.

\section{Premature newborn care through the support of the staff}

The parents perceived as difficulties and stress factors being in another city, leaving the other children to be in the hospital with the premature newborn and financial problems. The factors that facilitate that experience were the free access to meals and lodging as they were allocated by the direction of the hospital in a hostel located in front of the institution; the confidence in the team; and the availability of Neonatal Intensive Care Unit. It's being hard to keep away from the rest of the family, but I'm being well treated. In the Neonatal Intensive Care Unit everyone welcomes us well. I feel like he's being well assisted, I rely on the team because of the results we see and talking with the other mothers of premature infants. We realize the responsibility and commitment the team has (P1). I think the nurses take good care of him, I have no complaints, but it's very hard for me to know that he's there. He could be home with me, here I can't breastfeed him, only when he gets weight (P10). The Neonatal Intensive Care Unit, just for the name you know it's for a child who is very ill or recovering from something serious, but I know that here we count with good resour- ces, I'm not afraid because she's hospitalized as she's being assisted (P12).

Participants reported a good relationship with the team, especially nurses, who continuously take care of children. In addition, they reported feelings of respect and affection towards the professionals. Nurses are like my friends. They talk to me, calm me down, I have no reason to complain about them. They do it happily, they are very involved with children they take care of and with us, they do what it needs to be done and when children leave the NICU they feel really happy, we realize their joy, their excitement (P3). I like them very much, they are very friendly, they clear all the doubts that we have, both doctor and nurses. They answer all the questions, clear our doubts and are always available to us (P5). The service here is very good, they're very nice, humanized, they explain procedures very well and invite us to participate to take care of her, I rely on them (P6). The nurses take care of her, I always see the girls (nursing) looking after her, they clarify any doubts and explain. I have a good relationship with them because they teach me, show me how to take care of my daughter (P8).

The parents' participation in the babies' care was during hospitalization was pointed out. The parents carried out therapeutic touch, change their diaper, hold the babies, feed them (bottle or breast), bath them, among others, and realized their children's clinical situation improved after skin-to-skin contact and the bond strengthens: We can give Kangaroo care to our daughter, we can touch her, talk to her. This is very good, because it helps and calms her a lot (P1). You can see the difference when we have contact with her (P2). All the time I see her, I give her a bath, hold her, feed her. Now the girls (nurses) will teach me how to prepare her milk. I feel that she gets better when she is with me, she gained weight (P6). They (nurses) are very stimulating, they ask me to give Kangaroo care to my baby, encourage me to change the diaper. We observe and ask, because we have our anxieties and fears, and they teach everything, help us to be well prepared (P7). I'm there whenever I can. Sometimes I change her diaper when I can, I hold, breastfeed her, I think she gets better when I'm there (P11).

The fear related to home care after hospital discharge was also highlighted. However, it was reported the positive influence of the guidelines given by the staff in the hospital and just before discharge, what gave confidence to the parents for the activities they 
had to carry out at home with their children. We are really prepared to take him home. We can't wait. We know that he's being assisted here with all the resources, but we really wanted him to be at home, I'm looking forward to it, but I'm learning to take care of him with the staff, they teach me, when I have questions I always ask (P2). I'm a little scared, I think if something happens here he is well assisted, but I don't want something to happen at home and here I encourage her, but at home we're dumb. But they teach us so we can be prepared to take care of her at home (P3).

\section{Discussion}

The limitations of the study were: the restricted participation of only two fathers, the subjectivity inherent to the method and the short period of investigation.

Premature birth can be associated with several conditions like maternal age as some studies have shown that extreme ages ( $<19$ years and $>35$ years) are associated with prematurity ${ }^{(7-8)}$, as well as the level of education and antagonistic social-demographic conditions may also be associated with it ${ }^{(3)}$. Therefore, education and training are methods to promote knowledge and health practices to social changes.

Medical care during the prenatal period, especially in high-risk pregnancies, is essential, because it is possible, through mother and child assistance, to identify changes at an early stage and prevent damages. The results of this study indicate different causes of premature births. The assessment made by a team involved with qualified and expanded health care, as well as the appropriate assistance during the gestational period, conduct effective and necessary interventions to prevent complications that could cause neonatal morbidity and mortality ${ }^{(9-10)}$.

Complications in pregnancy can trigger preterm labor and the need of surgery (caesarean section). However, researches show that many cases end up in induced vaginal delivery or waiting to start naturally. It is important to analyze each situation, giving clear and precise information to the people involved and respect their beliefs and feelings related to the de- sired type of delivery ${ }^{(11)}$.

The Apgar score is a parameter used to evaluate the neonate health in the delivery room. Its application in the $1^{\text {st }}$ and $5^{\text {th }}$ minute after birth is extremely important and must be observed, especially in premature infants of low birth weight, to analyze the conditions at birth and minimize future damages ${ }^{(12)}$.

About pregnancy and premature birth, parents reported fear, insecurity, guilt, and anxiety because of the barriers to overcome. A study showed that the concerns and difficulties related to the children hospitalization occur because family members consider the hospital a strange and scary environment ${ }^{(2)}$.

The experience of having the newborns in Neonatal Intensive Care Unit is striking for the family, and demands the professionals create strategies so the parents can reorganize themselves socially, emotionally and psychologically, which is fundamental in the process of bond formation between them and the children ${ }^{(4)}$. During hospitalization, parents need to rely on the staff responsible for their children care, because the absence of appropriate follow-up or support to the families can trigger insecurity, inability, anger, guilt, fantasies and doubts about the child care ${ }^{(13)}$.

Most of the respondents were mothers and fathers, who worked and were responsible for their family keep. Recent studies show that some of the aspects that complicate family-centered care is the difficulty the parents to be in the unit, because they need to be involved with the activities at home and look after the other children, articulate and negotiate baby visits schedule, job and family chores ${ }^{(14-16)}$. The facilitators referred to in this study confirm the positive experiences of mothers of premature hospitalized infants because their children are alive and the technological resources and specialists for intensive and daily care ${ }^{(5)}$.

The findings show that parents were guided by the health care staff. The inclusion of the family in this activity requires that professionals are available and attentive to the interactions and the impact of the experiences, as well as they know adaptation dynamics 
and strategies. The bonds between the family and the child should be encouraged, and paying attention to the parents must be one of the priorities of the neonatology services so that they feel valued and active participants ${ }^{(5)}$. A study with parents who did not receive the team support in their involvement with the babies showed high level of stress, anxiety and unsatisfactory professional support, that is harmful during hospitalization and does not promote integral care ${ }^{(17)}$.

Despite they are afraid of leaving the hospital, parents look for this moment and, according to a recent study, it represents relief, because they understand they are assuming the responsibility for the baby care $^{(18)}$. Therefore, it is important to highlight the relevance of the guidelines given in the hospital and the instructions to follow at home.

This study can contribute to the newborns in hospital assistance since it confirms that the health team performs an important function by the families. In this context, the nursing staff appears as a facilitator of the adaptation process of the family because the participants shared information about the humanized assistance received through guidelines, bond strengthening, the Kangaroo care and effective interpersonal relationships. The reports reinforce the relevance these professionals have as listeners, friendly receptors and giving continuous home care. So, the research reveals the potential of family-centered assistance with inclusion strategies and investigation. To effectively develop this process, it is necessary to consider the individuality and uniqueness of each family and preemie newborn.

\section{Conclusion}

The parents realized that the hospitalization in a Neonatal Intensive Care Unit mobilizes different feelings related to prematurity as well as financial and social issues and the distance from homes and families. They showed learning, through the bond and trust, as an important activity of the nursing staff.

\section{Collaborations}

Pieszak GM and Paust AM contributed in the conception, design and data analysis as well as writing the article. Garcia GC Arrue AM, Neves ET and Machado LM contributed on relevant critical review of the intellectual content and on final approval of the version to be published.

\section{References}

1. Roseiro CP, Pereira KMP. Concepções de humanização de profissionais em Unidades de Terapia Intensiva Neonatal. Rev Estud Psicol. 2015; 32(1):109-19. doi: http://dx.doi. org/10.1590/0103-166X2015000100010.

2. Oliveira LL, Gonçalves AC, Costa JSD, Bonilha ALL. Maternal and neonatal factors related to prematurity. Rev Esc Enferm USP. 2016; 50(3):382-9. doi: http://dx.doi.org/10.1590/ S0080-623420160000400002.

3. Antunes SB, Paula CC, Padoin SMM, Trojahn TC, Rodrigues AP, Tronco CS. Hospitalization of newborns in Neonatal Unit: the meaning for the mother. Rev Rene. 2014; 15(5):796-803. doi: http://dx. doi.org/10.15253/2175-6783.2014000500009

4. Frigo J, Zocche DA, Palavro GL, Turatti LA, Neves ET, Schaefer TM. Percepções dos pais de recém-nascido prematuros em Unidade de Terapia Intensiva Neonatal. Rev Enferm UFSM. 2015; 5(1):58-8. doi: http://dx.doi. org/10.5902/2179769212900

5. Ribeiro CV, Soares MC, Torres AAP, Rosa SV, Meincke MK. Meanings of prematurity for mothers of newborns admitted to a neonatal intensive care unit. Rev Enferm UFPE on line [Internet]. 2014 [cited 2017 Aug 13]; 8(9):3106-11. Available from: http://www.revista.ufpe.br/revistaenfermagem/ index.php/revista/article/view/4718

6. Minayo MCS. Desafio do conhecimento: pesquisa qualitativa em saúde. São Paulo: Hucitec Abrasco; 2014. 
7. Gravena AAF, Paula MG, Marcon SS, Carvalho MDB, Pelloso SM. Maternal age and factors associated with perinatal outcomes. Acta Paul Enferm. 2013; 26(2):130-5. doi: http://dx.doi.org/10.1590/ S0103-21002013000200005

8. Souza ML, Lynn FA, Johnston L, Tavares ECT, Bruggemann OM, Botelho LJ. Fertility rates and perinatal outcomes of adolescent pregnancies: a retrospective population-based study. Rev LatinoAm Enfermagem. 2017; 25:e2876. doi: http:// dx.doi.org/10.1590/1518-8345.1820.2876

9. Brod FR, Rocha DLB, Santos RP. Knowledge and practices of mothers of premature newborns in the mainteining of breastfeeding. J Rev Fundam Care Online. 2016; 8(4):5108-13. doi: http:// dx.doi.org/ 10.9789/2175-5361

10. Pieszak GM, Neves ET, Jantsch, LB, Arrué AM, Zamberlan KC, Santos, RP. Caracterização de recém-nascidos em uma unidade de terapia intensiva de um hospital de ensino - 2002-2006. Rev Saúde. 2013; 39(2):141-8. doi: http://dx.doi. org/10.5902/223658348160

11. Neves ET, Silveira A, Arrué AM, Pieszak GM, Zamberlan KC, Santos RP. Network of care of children with special health care needs. Texto Contexto Enferm. 2015; 24(2):399-406. doi: http://dx.doi. org/10.1590/0104-07072015003010013

12. Junuário GC, Vieira CS, Nunes FDD, Gontijo TL, Cavalcante RB, Guimarães EAA. Maternal and neonatal characteristics from the live birth declaration. Rev Enferm UFPE on line [Internet]. 2016 [cited 2017 Aug 13]; 10(supl.9):3313-9. Available from: http://www.revista.ufpe.br/ revistaenfermagem/index.php/revista/article/ viewArticle/7403
13. Lopes BG, Borges PKO, Grden CRB, Coradassi CE, Sales CM, Damasceno NFP. Maternal mourning: pain and coping with the loss of a baby. Rev Rene. 2017; 18(3):307-13. doi: http://dx.doi. org/10.15253/2175-6783.2017000300004

14. Marski BSL, Custodio N, Abreu FCP, Melo DF, Wernet M. Hospital discharge of premature newborns: the father's experience. Rev Bras Enferm. 2016; 69(2):221-8. doi: http://dx.doi. org/10.1590/0034-7167.2016690203i

15. Medeiros AL, Santos SR, Cabral RWL, Silva JPG, Nascimento NM. Assessing nursing diagnoses and interventions in labour and high-risk pregnancies. Rev Gaúcha Enferm. 2016; 37(3):e55316. doi:http://dx.doi.org/10.1590/19831447.2016.03.55316

16. Soares LSF, Christoffel MM, Rodrigues EC, Machado MED, Cunha AL. The meanings of caring for pre-term children in the vision of male parents. Texto Contexto Enferm. 2016; 25(4):e1680015. doi:http://dx.doi.org/10.1590/0104 07072016001680015

17. Magliyah AF, Razzak MI. The Parents' Perception of Nursing Support in their Neonatal Intensive Care Unit (NICU) Experience. (IJACSA) Int J Adv Comp Sci Appl. 2015; 6(2):153-158. doi: http:// 10.14569/IJACSA.2015.060222

18. Pereira LB, Abraão ACFV, Ohara CVS, Ribeiro CA. Maternal experiences with of specificities prematurity that hinder breastfeeding. Texto Contexto Enferm. 2015; 24(1): 55-3. doi: http:// dx.doi.org/10.1590/0104-07072015000540014 